\title{
Evaluation of estradiol benzoate as a pre-treatment for oocyte recovery in sheep
}

\section{Avaliação do benzoato de estradiol com um pré-tratamento para a recuperação de oócitos em ovelhas}

\author{
Marilu Constantino Max ${ }^{1}$; Gustavo Martins Gomes Santos ${ }^{1}$; Fábio Morotti ${ }^{1}$; \\ Katia Cristina Silva-Santos ${ }^{2}$; Fabiana Andrade Melo-Sterza ${ }^{3}$; \\ Thales Ricardo Rigo Barreiros ${ }^{4}$; Marcelo Marcondes Seneda ${ }^{5 *}$
}

\begin{abstract}
The objective of this study was to compare the number of follicles, oocytes and the recovery rate in sheep submitted to the one-shot protocol with or without ovarian priming with estradiol benzoate (EB). Pluriparous non-lactating sheep $(n=33)$ with an average age of five years (range 4-6) and a body condition score of $3.0 \pm 0.3$ were divided into three groups. The one-shot group $(n=10)$ was treated with a subcutaneous implant containing $1.5 \mathrm{mg}$ of norgestomet from D0 to D10. The animals in this group were administered $0.04 \mathrm{mg}$ of D-cloprostenol, $200 \mathrm{IU}$ of follicle stimulating hormone (FSH) and 300 IU of equine chorionic gonadotropin (eCG) on D8. Animals in the EB group $(\mathrm{n}=11)$ received the same treatment as one-shot plus the administration of $0.6 \mathrm{mg}$ of EB on D0. In the untreated group $(\mathrm{n}=12)$, the animals received no hormone stimulation. The collection of the oocytes was performed by laparotomy $36 \mathrm{~h}$ after the administration of gonadotropins (D10). Oocytes were searched and classified based on morphology. An increase was observed $(\mathrm{p}<0.05)$ in the number of follicles aspirated in the one-shot $v s$. the EB and untreated groups (16.3 $\pm 5.6 v s .9 .5 \pm 2.4$ and $12.1 \pm 4.1)$, respectively. The average number of oocytes and the recovery rate were higher $(\mathrm{p}<0.05)$ in the one-shot and EB groups compared to the untreated group, resulting in $14.2 \pm 9.0$ and $87.1 \%(142 / 163), 11.0 \pm 6.2$ and $91.4 \%(122 / 134) v s .6 .8 \pm 3.5$ and $71.9 \%(82 / 114)$, respectively. It was concluded that the EB did not improve efficiency in the oneshot protocol, but was significantly better than in untreated animals.
\end{abstract}

Key words: Hormonal protocol, estradiol benzoate, sheep, OPU, oocyte recovery

\section{Resumo}

O objetivo deste estudo foi comparar o número de folículos, oócitos e a taxa de recuperação em ovelhas submetidas ao protocolo one-shot com ou sem priming ovariano de benzoato de estradiol (BE). Ovelhas não lactantes ( $\mathrm{n}=33$ ), multíparas, com idade média de cinco anos (intervalo 4-6) e um escore de condição corporal de $3,0 \pm 0,3$ foram divididas em três grupos. O grupo one-shot $(n=10)$ foi tratado com um implante subcutâneo contendo $1,5 \mathrm{mg}$ de norgestomet do D0 ao D10, além de receberem 0,04

\footnotetext{
${ }^{1}$ Discentes de Doutorado do Programa de Pós-Graduação em Ciência Animal, Universidade Estadual de Londrina, UEL, Londrina, PR. E-mail: marilucmax@hotmail.com; fabiomorotti@hotmail.com; gugamgs@hotmail.com

${ }^{2}$ Pós-doutoranda do Programa de Pós-Graduação em Ciência Animal, UEL, Londrina, PR. E-mail: kati_cris@hotmail.com

${ }^{3}$ Prof $^{a}$ do Dept ${ }^{\circ}$ de Zootecnia, Universidade Estadual do Mato Grosso do Sul, UEMS, Aquidauana, MS. E-mail fabiana.sterza@ gmail.com

${ }^{4}$ Prof. Dr. do Dept ${ }^{\circ}$ de Produção Animal, Universidade Estadual do Norte do Paraná, UENP, Bandeirantes, PR. E-mail: thalesrigo@ ffalm.br

${ }^{5}$ Prof. do Dept ${ }^{\mathrm{o}}$ de Clínicas Veterinárias, Universidade Estadual de Londrina, UEL, Londrina, PR. E-mail: mseneda@uel.br

* Author for correspondence
} 
mg de D-cloprostenol, 200 UI de hormônio folículo estimulante (FSH) e 300 UI de gonadotrofina coriônica equina (eCG) no D8. As ovelhas do grupo BE $(n=11)$ receberam o mesmo tratamento do oneshot e uma aplicação de $0,6 \mathrm{mg}$ de $\mathrm{BE}$ no $\mathrm{D} 0$. Os animais do grupo não tratado $(\mathrm{n}=12)$ não receberam hormônios. A aspiração folicular foi realizada por laparotomia 36 horas após a administração da gonadotrofina (D10) e os oócitos pesquisados e classificados com base na morfologia. Observou-se um aumento $(\mathrm{p}<0,05)$ no número de folículos aspirados no grupo one-shot comparado com os grupos $\mathrm{BE}$ e não tratado $(16,3 \pm 5,6$ vs. 9,5 $\pm 2,4$ e $12,1 \pm 4,1)$ respectivamente. O número médio de oócitos e taxa de recuperação foram superiores $(\mathrm{p}<0,05)$ nos grupos one-shot e $\mathrm{BE}$ em comparação com o grupo não tratado, o que resultou em $14,2 \pm 9,0$ e $87,1 \%$ (142/163), 11,0 $\pm 6,2$ e $91,4 \%$ (122/134) vs. 6,8 $8 \pm 3,5$ e $71,9 \%$ (82/114), respectivamente. Concluiu-se que a BE não aumentou a eficiência do protocolo one-shot, mas foi significativamente superior os animais não tratados.

Palavras-chave: Protocolo hormonal, benzoato de estradiol, ovelhas, OPU, recuperação de oócitos

The recovery of oocytes from live females by ovum pick-up (OPU) is widely performed in several species, most notably cattle. However, the commercial application of the technology in small ruminants is still limited and this technique is most frequently used in basic research (BALDASSARRE et al., 2004).

In sheep, multiple ovulation and embryo transfer programs (MOET) often result in failure as a consequence of low ovulation and fertilization rates and a high incidence of premature luteolysis. These causes account for $25 \%$ of MOET donors producing no transferable embryos by uterine flushing (BALDASSARRE et al., 1994). In this context, in vitro embryo production (IVEP) could avoid these problems and allow the use of older females and animals with some reproductive problems (BALDASSARRE et al., 2007).

The anatomical features represent a significant limitation in sheep due to the difficulty of transvaginal ovarian manipulation. Another limitation is the lack of priming protocols to promote adequate control of follicular waves and an increase in the number of recovered oocytes (BARTLEWSKI et al., 1999; GUINTHE; KOT; WILTIBANK, 1995).

Compared with untreated sheep, the treatment of donors with hormonal regimes results in an increased number of oocytes recovered and consequently, a higher number of in vitro produced embryos (BARIL, 2006). Protocols combining progesterone (P4), equine chorionic gonadotropin (eCG) and follicle stimulating hormone (FSH) associated with different strategies have been studied, but there is a lack of information on the use of estradiol benzoate (EB) for follicular wave synchronization (KELLY; KLEEMANN; WALKER, 2005).

The aim of this study was to evaluate the use of EB in an established hormonal protocol - one-shot (OS) - with regards to the number of follicles and oocytes and the recovery rate in sheep.

The experiment was conducted in South America, Brazil (23॰30’ 26' S latitude, 51॰14'06" $\mathrm{W})$, at the onset of the natural breeding season. The climate is subtropical with peak rainfall in summer.

Thirty-three crossbred (1/2 Texel blood) pluriparous sheep, tossed, non-lactating and clinically healthy, with an average age of five years (range 4-6) and a body condition score (BCS) of 3.0 \pm 0.3 (CALDEIRA; VAZ PORTUGAL, 1998) were used in this study. The animals were kept on a pasture composed of star grass (Cynodon pletostachyrus pilger) and thick bush grass (Paspalum notatum) under continuous grazing with access to mineralized salt and water ad libitum and $200 \mathrm{~g}$ of soybeans/animal at night.

Animals were divided into three groups according to the hormonal treatment (Figure 1). The OS group $(\mathrm{n}=10)$ was treated with a subcutaneous implant containing $1.5 \mathrm{mg}$ of norgestomet (Crestar ${ }^{\circledR}$, Intervet, Holland) from $\mathrm{D}_{0}$ to $\mathrm{D}_{10}$. The animals in this group were administered $0.04 \mathrm{mg}$ of D-cloprostenol 
(Preloban ${ }^{\circledR}$, Intervet, Holland), 200 IU of follicle stimulating hormone (FSH) (Pluset ${ }^{\circledR}$, Hertape Calier, Spain) and 300 IU of equine chorionic gonadotropin (eCG) (Folligon $\AA$, Intervet, Holland) at D8. Animals in the EB group $(\mathrm{n}=11)$ received the same treatment as OS, plus the administration of 0.6 mg of EB (Estrogin ${ }^{\circledR}$, Famavet, Brazil) on $\mathrm{D}_{0}$. In the untreated group $(\mathrm{n}=12)$, the animals received no hormone stimulation. The only difference between the EB and OS groups was the administration of $0.6 \mathrm{mg}$ of $\mathrm{EB}$ on $\mathrm{D}_{0}$. Animals in the untreated group received a placebo injection of $0.6 \mathrm{~mL}$ saline intramuscularly (im) on the same days and times that the animals of the other groups were injected.

Figure 1. Experimental design of the one-shot and estradiol benzoate group administered in sheep pre-follicular aspiration.

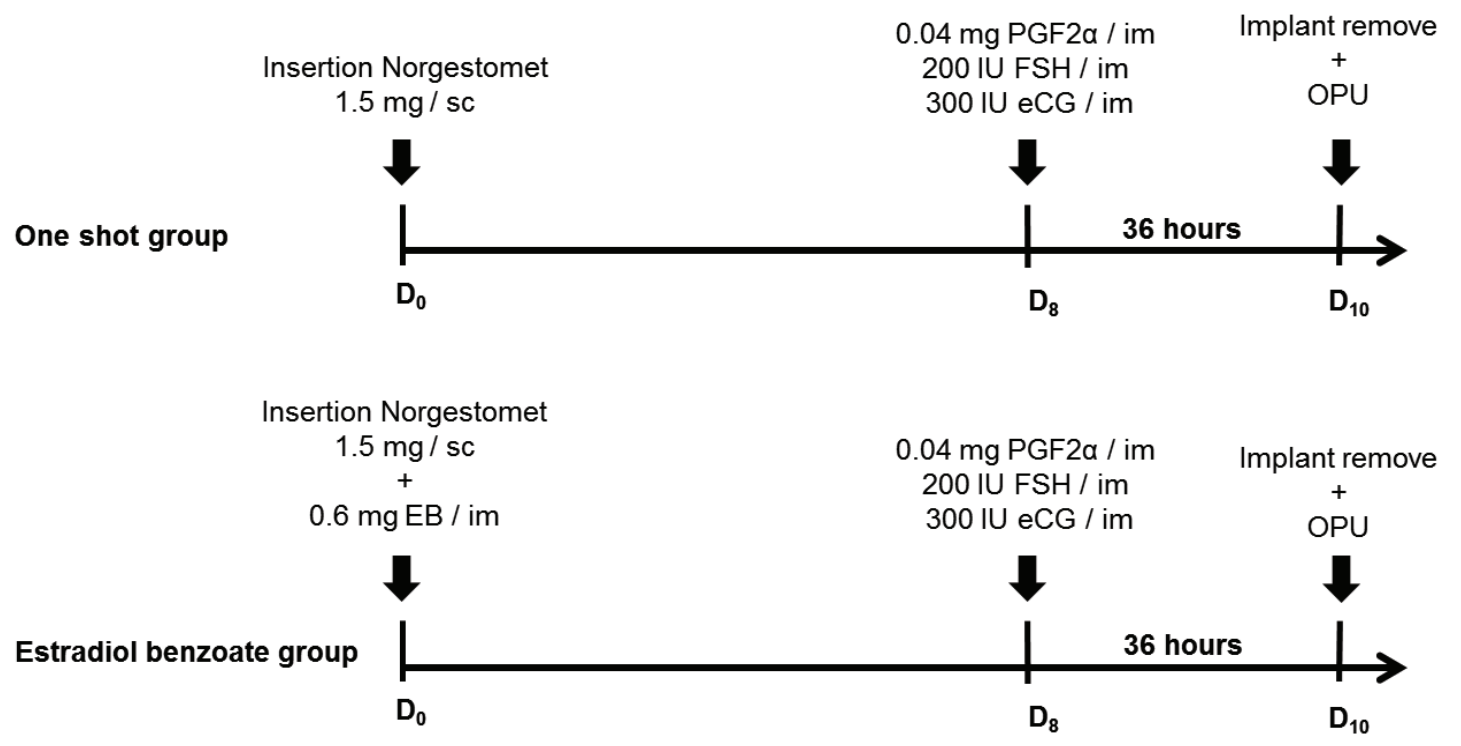

Source: Elaboration of the authors.

Ovaries were exposed by paramedian laparotomy $36 \mathrm{~h}$ (D10) after the administration of gonadotropins and follicular aspirations were performed according to the procedure reported by Ptak et al. (1999). The medium used for aspiration was saline solution supplemented with $0.05 \mathrm{mg} /$ $\mathrm{mL}$ heparin. All visible follicles $(\geq 2 \mathrm{~mm})$ on both ovaries were counted and aspirated.

After OPU and flushing of the system, classification of the oocytes was performed using a stereomicroscope (Meiji Techno EMZ, Japan) considering the presence of cumulus cells and the oocyte aspect, as follows: good - more than three layers of cumulus cells, regular - at least one layer, denuded - partly covered with cumulus cells or without cumulus cells, and atretic - dark cumulus oophorus and signs of cytoplasmic degeneration (SENEDA et al., 2001). All procedures were performed by the same veterinarian.

We evaluated the number of follicles, the number and quality of oocytes and the recovery rate for each group. Individual information from each sheep was collected in a data set for statistical analysis.

The quantitative variables were analyzed by analysis of variance (ANOVA) and if the effect of group was significant, the data were examined by the Tukey test. The frequency variables were analyzed by the Chi-squared test. All data were evaluated using the MINITAB15 statistical software 
(Minitab®) Pennsylvania, United Kingdom) program adopting a $5 \%$ level of significance for rejecting H0 (null hypothesis); namely, a level of significance $<0.05$ was considered to indicate the effect of the categorical variables and their interactions. The data are given as the mean and standard deviation $(\mathrm{M} \pm \mathrm{SD})$.

The administration of EB 8 days prior to the OS protocol was not effective in increasing the total number of follicles and oocytes. The number of viable oocytes and recovery rate were similar between EB and OS groups (Table 1).

Table 1. Average number of follicles, oocytes and viable oocytes, as well as the recovery rate obtained from adult sheep subjected to hormonal protocols pre-follicular aspiration at the beginning of the breeding season.

\begin{tabular}{lcccc}
\hline Groups & $\begin{array}{c}\text { Follicle } \\
(\mathrm{M} \pm \mathrm{SD})\end{array}$ & $\begin{array}{c}\text { Oocyte } \\
(\mathrm{M} \pm \mathrm{SD})\end{array}$ & $\begin{array}{c}\text { Viable oocyte } \\
(\mathrm{M} \pm \mathrm{SD})\end{array}$ & $\begin{array}{c}\text { Recovery rate } \\
\text { Oocytes/follicles }(\%)\end{array}$ \\
\hline Untreated $(\mathrm{n}=12)$ & $9.5 \pm 2.4^{\mathrm{b}}$ & $6.8 \pm 3.5^{\mathrm{b}}$ & $6.1 \pm 3.2^{\mathrm{b}}$ & $71.9(82 / 114)^{\mathrm{b}}$ \\
Estradiol benzoate $(\mathrm{n}=11)$ & $12.1 \pm 4.1^{\mathrm{b}}$ & $11.0 \pm 6.2^{\mathrm{b}}$ & $10.5 \pm 6.1^{\mathrm{ab}}$ & $91.4(122 / 134)^{\mathrm{a}}$ \\
One-shot $(\mathrm{n}=10)$ & $16.3 \pm 5.6^{\mathrm{a}}$ & $14.2 \pm 9.0^{\mathrm{a}}$ & $14.0 \pm 8.0^{\mathrm{a}}$ & $87.1(142 / 163)^{\mathrm{ab}}$ \\
\hline
\end{tabular}

Values followed by different letters in the same column indicate differences $(p<0.05)$.

Source: Elaboration of the authors.

To promote the regression of follicles and the emergence of a new follicular wave, the EB was associated with a source of $\mathrm{P} 4$, as has been described in cattle (BÓ et al., 1994). This was expected to provide a better synchrony of follicular development leading to a better result when FSH and eCG (oneshot) are applied. In cattle, the application of EB $\sim 4$ days prior to FSH treatment has resulted in a better superovulatory response (NASSER et al., 1993). However, in our experimental conditions, the number of oocytes obtained in ewes treated with EB was below those who received only OS. Some explanations may be considered; for example, the eight days interval between the application of EB and the gonadotropins may have been too long considering the possibility of emergence of a new wave three to four days after the application of estradiol-17 $\beta$ and P4 (BARRET et al., 2008).

The OS protocol provided an average of 16 follicles aspirated per donor, which is comparable with the average found by Baldassarre et al. (1996), who reported 12 follicles using the same protocol. In animals that did not receive hormonal stimulation, 9 follicles per donor were obtained, which is comparable with that found by Kühholzer et al. (1997), who reported 7 follicles per animal. Significantly fewer follicles were available for aspiration in the EB group compared with the OS group (12.1 vs. 16.3, $\mathrm{p}<0.05)$, suggesting the "early" administration of EB may have altered follicular availability for gonadotropin stimulation under the one-shot protocol.

Sheep that received the OS protocol produced an average of 14 oocytes, which is comparable with that reported by Baldassarre et al. (1996) at 9.1 oocytes. It was also at par with the values described in Brazil, with 14.3 oocytes from different breeds subjected to the OS regime (BASSO et al., 2008). The addition of EB to the OS protocol resulted in fewer oocytes (11), which is consistent with the fact that the EB group had fewer follicles compared to the OS group. The untreated females presented an average of 7 oocytes, which is similar to the result obtained in Merino sheep (5) without hormonal stimulation (KÜHHOLZER et al., 1997).

In conclusion, the better results were obtained from hormonally treated donors when compared 
with non-treated animals. The administration of estradiol benzoate eight days prior to one shot treatment did not improve its efficiency and the one shot protocol was significantly better of those from untreated animals.

\section{References}

BALDASSARRE, H.; DE MATOS, D. G.; FURNUS, C. C.; CASTRO, T. E.; CABRERA FISCHER, E. I. Technique for efficient recovery of sheep oocytes by laparoscopic folliculocentesis. Animal Reproduction Science, Amsterdam, v. 35, n. 1-2, p. 145-150, 1994.

BALDASSARE, H.; FURNUS, C. C.; DE MATOS, D. G.; PESSI, H. In vitro production of sheep embryos using laparoscopic folliculocentesis; alternative gonadotrophin treatments for stimulation of oocyte donors. Theriogenology, Philadelphia, v. 45, n. 3, p. $707-$ 717, 1996.

BALDASSARRE, H.; RAO, K. M.; NEVEU, N.; BROCHU, E.; BEGIN, I.; BEHBOODI, E.; HOCKLEY, D. K. Laparoscopic ovum pickup followed by in vitro embryo production for the reproductive rescue of aged goats of high genetic value. Reproduction, Fertility and Development, Collingwood, v. 19, n. 5, p. 612-616, 2007.

BALDASSARRE, H.; WANG, B.; PIERSON, J.; NEVEU, N.; SNEEK, L.; LAPOINTE, J.; COTE, F.; KAFIDI, N.; KEEFER, C. L.; LAZARIS, A.; KARATZAS, C. N. Prepubertal propagation of transgenic cloned goats by laparoscopic ovum pick-up and in vitro embryo production. Cloning Stem Cells, Edinburgh, v. 6, n. 1, p. 25-29, 2004.

BARIL, G. Ovum pick-up em caprinos e ovinos. In: Biotecnologia da reprodução em pequenos ruminantes: produção de embriões por transferência nuclear (clonagem). Fortaleza: Multicolor, 2006. p. 3045.

BARRET, D. M. W.; BARTLEWSKI, P. M.; DUGGAVATHI, R.; DAVIES, K. L.; HUCHKOWSKY, S. L.; EPP, T.; RAWLINGS, N. C. Synchronization of follicular wave emergence in the seasonally anestrous ewes: The effects of estradiol with or without medroxyprogesterone acetate. Theriogenology, Philadelphia, v. 69, n. 7, p. 827-836, 2008.

BARTLEWSKI, P. M.; BEARD, A. P.; COOK, S. J.; CHANDOLIA, R. K.; HONARAMOOZ, A.; RAWLINGS, N. C. Ovarian antral follicular dynamics and their relationships with endocrine variables troughout the oestrous cycle in breeds of sheep differing in prolificacy. Journal of Reproduction and Fertility, Cambridge, v. 115, n. 1, p. 111-124, 1999.

BASSO, C. A.; MARTINS, J. F. P.; FERREIRA, C. R.; ERENO, A.; TANNURA, J.; TABET, A.; FIGUEIREDO, C. L.; OLIVEIRA, P. C.; PONTES, J. H. F. Produção in vitro de embriões ovinos: aspectos da técnica de aspiração folicular e do tratamento hormonal de doadoras. $O$ Embrião, Jaboticabal, v. 38, p. 9-13, 2008.

BÓ, G. A.; ADAMS, G. P.; PIERSON, R. A.; CACCIA, M.; TRIBULO, H.; MAPLETOFT, R. J. Follicular wave dynamics after estradiol-17 $\beta$ treatment of heifers with a progestogen implant. Theriogenology, Philadelphia, v. 41, n. 8, p. 1555-1569, 1994.

CALDEIRA, R. M.; VAZ PORTUGAL, A. Condição corporal: conceitos, métodos de avaliação e interesse da sua utilização como indicador na exploração de ovinos. Revista Portuguesa de Ciências Veterinárias, Lisboa, v. 93, n. 4, p. 95-102, 1998.

GUINTHER, O. J.; KOT, K.; WILTIBANK, M. C. Associations between emergence of follicular waves and fluctuations in FSH concentrations during the estrous cycle in ewes. Theriogenology, Philadelphia, v. 43, n. 3, p. $689-703,1995$.

KELLY, J. M.; KLEEMANN, D. O.; WALKER, S. K. Enhanced efficiency in the production of offspring from four to eight week old lambs. Theriogenology, Philadelphia, v. 63, n. 7, p. 1876-1890, 2005.

KÜHHOLZER, B.; MULLER, S.; TREUER, A.; SEREGI, J.; BESENFELDER, U.; BREM, G. Repeated endoscopic ovum pick-up in hormonally untreated ewes: a new technique. Theriogenology, Philadelphia, v. 48, n. 4, p. 545-550, 1997.

NASSER, L.F.;ADAMS, G.P.; BÓ, G. A.; MAPLETOFT, R. J. Ovarian superstimulatory response relative to follicular wave emergence in heifers. Theriogenology, Philadelphia, v. 40, n. 4, p. 713-724, 1993.

PTAK, G.; DATTENA, M.; LOI, P.; TISCHNER, M.; CAPPAI, P. Ovum pick-up in sheep: efficiency of in vitro embryo production, vitrification and birth of offspring. Theriogenology, Philadelphia, v. 52, n. 2, p. 1105-1114, 1999.

SENEDA, M. M.; ESPER, C. R.; GARCIA, J. M.; DE OLIVEIRA, J. A.; VANTINI, R. Relationship between follicle size and ultrasound-guided transvaginal oocyte recovery. Animal Reproduction Science, Amsterdam, v. 67, n. 1-2, p. 37-43, 2001. 
